\title{
Una exposició en plural. Feminismes! (CCCB. Barcelona, 19 de juliol del 2019 - 5 de gener del 2020)
}

\section{PAOLA LO CASCIO}

Universitat de Barcelona (Espanya)

orcid.org/0000-0002-1565-5566

doi: https://dx.doi.org/10.7238/dd.voi8.3188

Una part decisiva del missatge que vol transmetre l'exposició Feminismes!, que es va poder veure des del juliol fins al gener al Centre de Cultura Contemporània de Barcelona (CCCB) - es va prorrogar uns mesos per la bona acollida que va tenir-, està continguda en el plural del seu títol. No deixa de ser tota una declaració de principis, no només perquè intenta connectar experiències del moviment de les dones al llarg del temps (amb els dos nodes importants dels anys setanta i de les primeres dècades del nou millenni), sinó també perquè incideix en la diversitat de les formes d'expressió escollides i en l'evolució plural que ha tingut el moviment en els últims cinquanta anys, incorporant noves lluites, noves agències i noves fites.

Feminismes!, en realitat, està dividida en dues exposicions diferenciades, connectades per una passarella que reconstrueix la cronologia de l'evolució dels moviments feministes des dels anys setanta fins avui en dia.

La primera recull les obres de la Verbund Collection de Viena, una collecció privada formada sota la iniciativa de la companyia elèctrica homònima. S'hi poden admirar les obres, amb diferents formats — des del figuratiu fins al performatiu, l'audiovisual i el fotogràfic-, de més de setanta artistes nascudes entre 1928 i 1958.

Aquesta primera exposició s'organitza en diferents àmbits, que engloben aspectes centrals del moviment en els anys setanta: la superació de la representació de la dona com a mare, com a mestressa de casa i com a esposa; la reclusió i l'evasió; l'alter ego i la representació d'aquests papers com a farsa, paròdia i joc de rol, i la sexualitat femenina enfront de l'objectivació i dels dictats de la bellesa normativa. En definitiva, reflecteix l'eclosió seminal de la politització de l'esfera privada, que ha estat el motor de canvi plantejat pel feminisme de la segona onada. Entre les artistes seleccionades 
hi ha una gran diversitat de noms i de formes d'expressió artística. Entre elles cal remarcar l'obra audiovisual d'Annegret Soltau pel que fa a l'eix de la maternitat; la de l'holandesa Margot Pilz, que amb una sèrie fotogràfica impactant treballa la reclusió (també hi ha obres de diferents artistes sud-americanes que incideixen en el caràcter sexualitzat de la repressió viscuda a les dictadures d'aquella època a Xile o a l'Argentina, i de Pilar Aymerich en el cas de Catalunya); o, encara, en l'àmbit de la sexualitat, la de Lydia Benglis, que va trencar motlles amb un autoretrat amb un enorme consolador entre les cames, i la de Penny Slinger amb els seus autoretrats de núvia, on mostra la seva vagina dins d'un pastís de noces de cartró; o la d'Eva Patrum, artista polonesa que a mitjan anys setanta jugava amb el maquillatge per impugnar les formes de la bellesa imposada pel patriarcat i per reivindicar una nova estètica feminista, alliberada dels dictats masculins.

La proposta artística feta en aquesta primera exposició - comissariada per Gabriele Schor, austríaca, publicista, escriptora, crítica d'art i fundadora i directora de la collecció vienesa Sammlung Verbund - recull i amplifica l'experiència de més de setanta trajectòries de dones artistes. Com a dones implicades en el moviment d'aquell moment i, alhora, com a artistes, reivindiquen la seva agència en un món històricament masculinitzat (encara al final dels anys vuitanta es calcula que només un $5 \%$ de les seccions d'art modern dels museus acollien obres de dones) desplegant un arsenal disruptiu tant pel que fa als continguts i a les mirades com a les formes d'expressió.

La passarella conceptual que porta a la segona exposició està constituïda per una secció amb plafons en què es reconstrueix l'evolució del moviment de les dones des dels anys setanta fins a l'actualitat a Catalunya, amb una atenció especial a l'afirmació del còmic i de la novella gràfica feta per dones. La secció compleix bàsicament dos objectius: resseguir com s'han multiplicat les reivindicacions del moviment i observar el seu caràcter multiforme - que mentre s'enriqueix no perd la capacitat de vincular passat, present i futur-, i preparar a qui està experimentant (més que no pas visitant) Feminismes! per a la seva última exposició, centrada en l'obra d'una vintena d'artistes catalanes i del conjunt d'Espanya.

Aquesta segona exposició, «Coreografies del gènere», ha estat comissariada per Marta Segarra, catedràtica de literatura francesa i d'estudis 
de gènere a la Universitat de Barcelona i directora de recerca al Laboratoire d'Études de Genre et de Sexualité (LEGS) al Centre National de la Recherche Scientifique, i recull l'enfocament que ha sabut donar el moviment feminista als reptes del nostre temps. La interseccionalitat és absolutament central en aquesta exposició, com es reflecteix en les seccions que la componen: «Ser dona no és natural, desconstrucció del binarisme de gènere»; «Travessar fronteres, estendre ponts, descolonitzar el feminisme»; «Sexualitat i violència»; «Recosir-nos al món, ecofeminisme i posthumanitat». Així, sobresurten Helena Cabello i Anna Carceller, que fan una lectura performativa de l'obra de Judith Butler inclosa en la secció sobre la desconstrucció del binarisme; o Daniela Ortiz, que denuncia a través de la fotografia el racisme institucional en la secció de descolonització del feminisme; o, encara, Maria Llopis, l'obra de la qual forma part de la secció dedicada a la sexualitat i a la violència. No sembla pas una casualitat que el recorregut de l'exposició es clogui amb La cara B del turisme a Barcelona, una obra sobre l'explotació de les kellys realitzada per diferents artistes amb les mateixes treballadores, probablement el recordatori més eficaç que la intenció del conjunt de Feminismes! és poder parlar més del que passa a fora del CCCB que no pas del que passa a dins.

En aquest sentit, i més enllà de la selecció de les obres, el dibuix conceptual del conjunt de les dues exposicions ens parla de la vitalitat del moviment, que sembla haver estat més capaç que altres experiències reivindicatives de travessar la modernitat líquida amb un cert èxit, conservant els vincles amb les lluites del passat però projectant-se cap al futur. Això no vol dir pas que no hagi tingut, no tingui i no tindrà els seus debats interns, sovint extremadament durs. Tanmateix, avui en dia sembla ser un dels vectors de democratització més forts a escala global. La seva recepta, probablement, ha estat la que es fa patent en el títol del conjunt expositiu: la pluralitat —de subjectes, de lluites, de mirades, de formes de reivindicació i d'expressió - com a element clau a l'hora d'entomar de forma eficaç la fragmentació i la pèrdua de certeses del nostre temps. 